\title{
ANALYSIS OF AIRBORNE DUST AS A RESULT OF PLASTER CAST SAWING
}

\author{
Anko Antabak ${ }^{1}$, Damir Halužan ${ }^{1}$, Abdulah Chouehne ${ }^{2}$, Marko Mance ${ }^{3}$, Nino Fuchs ${ }^{3}$, \\ Ivica Prlić ${ }^{4}$ Ivan Bešlić ${ }^{4}$ and Zvjezdana Bencetić Klaić
}

\begin{abstract}
${ }^{1}$ Department of Surgery, Zagreb University Hospital Center and School of Medicine, University of Zagreb, Zagreb, Croatia; ${ }^{2}$ School of Medicine, University of Zagreb, Zagreb, Croatia; ${ }^{3}$ Department of Surgery, Zagreb University Hospital Center, Zagreb, Croatia; ${ }^{4}$ Institute of Medical Research and Occupational Health, Zagreb, Croatia; ${ }^{5}$ Andrija Mohorovičić Geophysical Institute, Department of Geophysics, Faculty of Science, University of Zagreb, Zagreb, Croatia
\end{abstract}

\begin{abstract}
SUMMARY - Plaster splints are used daily in surgical and orthopedic fields in order to immobilize injured children and adults. The aim of this study was to measure the aerodynamic diameter and concentration of dust particles in the air caused by sawing plaster splints (calcium sulfate dehydrate). We performed fractional measurements of airborne dust particles. The measured particles, which can potentially be inhaled, may have a specific negative effect on human health. Measurements were conducted in laboratory research facilities that simulated hospital conditions within a casting room and the associated waiting room. Measurements within the casting room were made using two particle collector devices and one laser photometer. The measurement for the simulated waiting room was performed using the same principles and devices. The collected plaster dust particles differed in aerodynamic diameter and concentration according to the various locations observed. The highest concentration of particles of all sizes was recorded at the site of cast sawing. There was direct correlation between distance from the source and concentration of airborne particles; this concentration was lowest in the waiting room. The concentrations of plaster dust recorded were lower than the recommended minimal limit values for total and respiratory fractions in Croatia. Accordingly, it can be assumed that sawing of plaster splints has no harmful health effects on the exposed patients and health personnel.

Key words: Casts, surgical; Calcium sulfate; Air pollutants - toxicity; Orthopedic fixation devices; Dust - adverse effects
\end{abstract}

\section{Introduction}

We regard dust as small, solid particles found in the air or on solid surfaces. The main characteristics of dust include size, shape, surface and chemical structure. Exposure to dust increases the risk of pulmonary and cardiovascular diseases, as well as lung cancer. Tissue damage is related to the size, concentration, chemical properties and time of exposure to these particles ${ }^{1-3}$.

Correspondence to: Prof. Anko Antabak, MD, PhD, Department of Surgery, Zagreb University Hospital Center and School of Medicine, University of Zagreb, Kišpatićeva 12, HR-10000 Zagreb, Croatia

E-mail: aantabak@kbc-zagreb.hr

Received March 15, 2017, accepted October 3, 2017
Since we are aware of this correlation, we can introduce and take actions to reduce exposure to such agents, and thus prevent diseases caused by long term exposure to dust particles.

Plaster is made of calcium sulfate and water with a chemical formula of $\mathrm{CaSO} 4 \times 2 \mathrm{H} 2 \mathrm{O}$. It belongs to the group of sulfates, which includes salts of sulfuric acid often present in the Earth's crust. This group of inorganic matter has the principal characteristic that allows it to react chemically with water to form a highly plastic compound. This plasticity allows it to be shaped easily, gradually hardens, and eventually dries into a solid structure with specific mechanical properties ${ }^{4}$.

Plaster utilization gained widespread popularity in the mid $-19^{\text {th }}$ century. It was first used by Matthys, a 


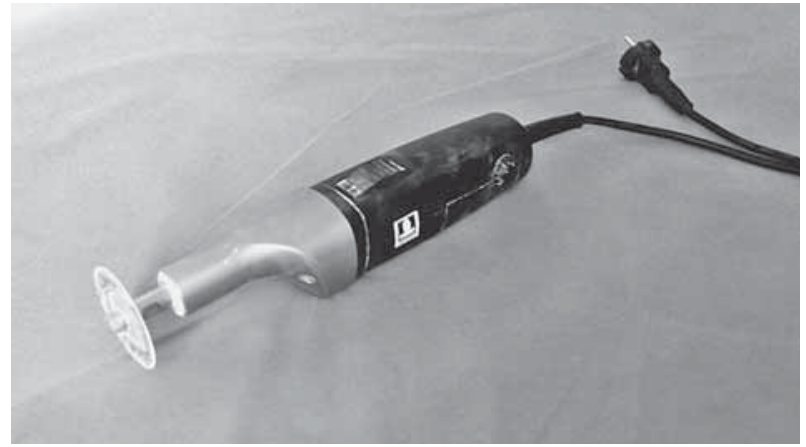

Fig. 1. Electric oscillating cast cutting saw $H E B U$ Oscillo-Saw GOLD II saw used for removal of medical plaster casts and splints (HEBUmedical GmbH, Tuttlingen, Germany).

Dutch physician, who published a pamphlet on the use of plaster in the treatment of bone fractures in $1852^{5}$. Health institutions in Croatia and throughout the world are still using this model in daily surgical and orthopedic practice for treating injured children and adults 5 . Removal of these plaster immobilizations is performed by medical technicians. Plaster splint is cut longitudinally using a saw (Fig. 1), which uses finely serrated surface vibration and crumbles plaster into solid dust particles.

The speed of deposition of airborne particles is proportional to their size, or aerodynamic diameter. Particles larger than 100 microns are retained briefly in the air and quickly fall to the ground while particles of 0.1 to 10 microns are deposited much more slowly. The particles of less than 0.1 microns $(100 \mathrm{~nm})$ are suspended in the air for the longest period. All particles that can be inhaled during normal breathing are defined as inhalable; the larger the particle, the lower is the likelihood that we will breathe it in (inhalability). The most dangerous particles for our health are those termed respirable, i.e. particles that are small enough to travel deep into our airways and reach the site of gas exchange. The smaller the particles, the more respirable they become.

During a typical eight-hour working day in the confinements of a casting room, the medical technician removes dozens of plaster immobilizations, thus filling the surrounding air with dust particles from the crushed plaster splints $(\mathrm{CaSO} 4 \times 2 \mathrm{H} 2 \mathrm{O})$. The time that the particles remain in the air mostly depends on their size and the air flow in the room. In such extreme conditions, health workers and patients, both adults and children, are exposed to a large quantity of inhalable and respirable dust particles.

To our knowledge, there is no published study regarding the size, concentration and chemical composition of dust in the air of hospital facilities. The aim of our study was to measure three fractions (PM10, PM2.5 and PM1) and the concentration of airborne particulate matter in the casting room and waiting room during sawing of plaster immobilizations. We also measured the concentration of two fractions of particulate plaster matter (PM10 and PM2.5) and the percentage of plaster particles in these two fractions considering different locations where simulated and multiple measurements were taken (two points in the casting room and two in the waiting room). We wanted to determine whether the measured concentrations of airborne particulate plaster matter at each measurement point met the legally permissible concentration level.

\section{Material and Methods}

For medical research, it is a standard to measure three fractions of dust particles in the air, as follows: particle fraction with aerodynamic diameter of $10 \mathrm{mi}-$ crons (PM10), 2.5 microns (PM2.5) and up to $1 \mathrm{mi}^{-}$ cron (PM1). They can be measured continuously in time using a laser photometer or by the gravimetric method (i.e. collecting particulate matter by inertial impaction on filters over a prolonged time interval and then using weight measurements to determine the amount). The gravimetric method is more accurate and is generally used as the reference method for correcting data obtained by other methods ${ }^{6-8}$. However, it cannot determine the mean concentration of PM in a time interval of less than a few hours. In contrast, by using laser photometer, it is possible to determine the mean concentrations of $\mathrm{PM}$ in intervals as short as every second but unfortunately, inaccuracies are known to occur, especially for particles with small fractions. Therefore, the data obtained by laser photometer must be corrected and it is done by comparing initial results with the reference gravimetric photometric data.

In our experiment, we sawed 34 forearm eightlayered circular plaster splints with bandage width of $10 \mathrm{~cm}$. The materials used were produced under the name Cellona (Lohman \& Rauscher, Austria). All plasters contained less than $10 \%$ moisture, measured 


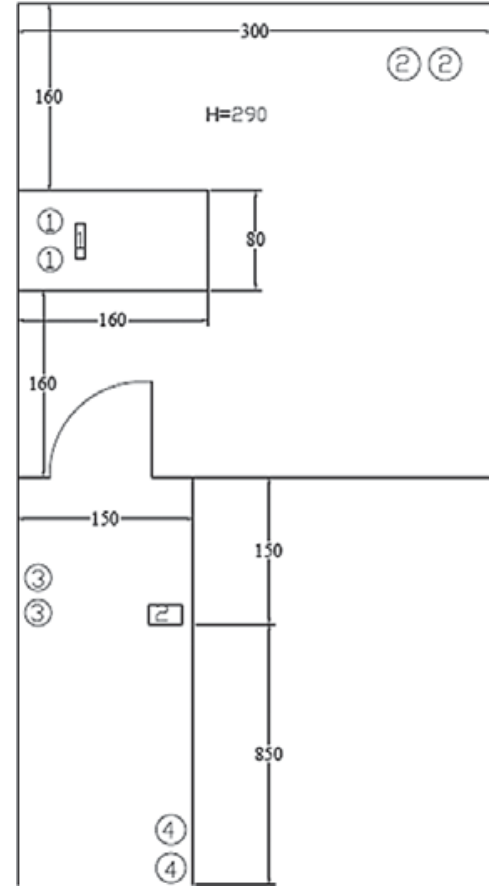

Fig. 2. Room layout and locations of particle collectors.

$\mathrm{H}=$ height of the room, with all measurements expressed in $\mathrm{cm}$; circles (1-4) indicate locations of particle collectors for PM10 and PM2.5 airborne particles; squares (1-2) indicate locations of laser photometers, where 1 is the 8533 model and 2 the 8520 model

by a professional moisture meter, Gann Hydromette Compact B (Gann Mess u. Regeltechnik GmbH, Gerlingen, Germany) $)^{9}$. To measure the aerodynamic diameter and particle concentrations of plaster dust particles at various points in the room, ten measuring devices were used. During the experiment, eight collectors of particulate matter, Airmetrics-MiniVol (Airmetrics, Springfield, OR, USA), with a constant flow rate of $5 \mathrm{~L} / \mathrm{min}$, collected samples of PM10 and PM2.5 fractions at four different measuring points. Samples were collected using the above-mentioned method of inertial impaction on filters of quartz fiber with a diameter of $47 \mathrm{~mm}$, while the concentrations were gravimetrically determined in accordance with the Croatian normative standards HRN EN 12341.

For the purpose of continuous monitoring of the mass concentration of particulate matter, two laser photometers, Dusttrak Aerosol Monitor 8533 and Dusttrak Aerosol Monitor 8520 (TSI Inc., Shoreview, MN, USA) were placed in two different locations, i.e. one directly within the sawing zone and the other one in the area in front of the casting room, as shown in
Figure 2. The laser photometers determined the mass concentration of total suspended particles and the concentrations of PM10, PM2.5 and PM1 fractions of particulate matter at the same time every 10 seconds. The sawing room was about $35 \mathrm{~m}^{3}$ in size and the arrangement of the furniture and ventilation conditions was almost identical to that in most plaster rooms in Croatian hospitals. Temperature and humidity in the work area were constant and monitored by a professional weather station, ETH 880 Digital Thermo-Hygrometer (Oregon Scientific, Inc., Hunghom Kowloon, Hong Kong).

Experimental measurements were obtained in two separate rooms. Two collectors and a laser photometer (Model 8533) were placed in the casting room, $40 \mathrm{~cm}$ away from the table for plaster sawing (at a height of $120 \mathrm{~cm}$ ), and PM10 and PM2.5 particulate matter was measured. These two devices were considered station 1 (MP-1). The laser photometer measured continuously for five hours and fifty minutes. It recorded the mass concentration of total suspended particles and the mass concentration of fractions with aerodynamic diameter of up to 1,2.5 and 10 microns. A suction pipe instrument was set so that the room air entered the instrument at a height of $170 \mathrm{~cm}$ from the ground, which corresponds to the average breathing height of adult humans according to the EU Council Directive to limit values of sulfur dioxide, nitrogen dioxide and oxides of nitrogen, particulate matter and lead in ambient air 1999/30/EC from $1999^{10}$. In the same room, another pair of collectors measured PM10 and PM2.5 particulate matter at a distance of three meters from the cutting zone (MP-2).

The collectors and laser photometer were also placed in the waiting room at a distance of $150 \mathrm{~cm}$ from the door (MP-3). The laser photometer in the waiting room continuously measured for a total of five hours and six minutes and recorded only fraction concentrations of PM2.5. In the waiting room, two collectors for the measurement of PM10 and PM2.5 (MP-4) were set up at a distance of ten meters from the door. The collector assembly scheme is shown in Figure 2.

The method of work simulation included sawing of each plaster, time recording, opening the door of the room, a short break and repeating the process of sawing the remaining plaster splints. One of the authors sawed plaster splints during the experiment while 


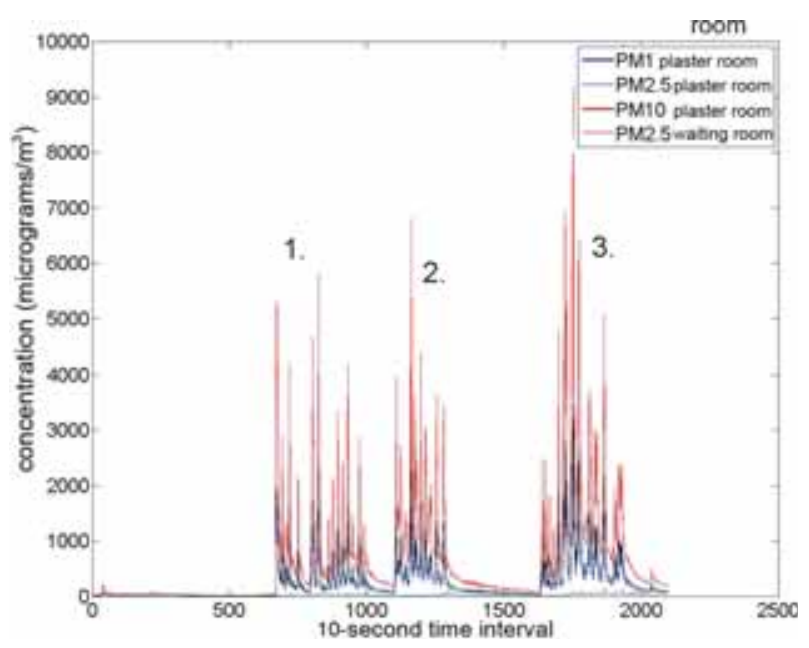

Fig. 3. Mean dust particle concentrations measured every 10 seconds in the plaster room and patient waiting room during sawing of 34 plaster splints. Three different sets of sawing are listed by numbers: 1 (from 666 to 1000 ten-second interval); 2 (from 1100 to 1278 ten-second interval); and 3 (from 1622 to 1944 ten-second interval).

$\mathrm{x}$ axis - ten second interval; $\mathrm{y}$ axis - concentration $\left(\mu \mathrm{g} / \mathrm{m}^{3}\right) ; \mathrm{PM} 1$ plaster room - concentration fraction of airborne particles with aerodynamic diameter of up to $1 \mu \mathrm{m}$ within the room; PM2.5 plaster room - concentration fraction of airborne particles with aerodynamic diameter of up to $2.5 \mu \mathrm{m}$ within the room; PM10 plaster room - concentration fraction of airborne particles with aerodynamic diameter of up to $10 \mu \mathrm{m}$ within the room; PM2.5 waiting room - concentration fraction of airborne particles with aerodynamic diameter of up to $2.5 \mu \mathrm{m}$ within the room

wearing a protective mask, hat and eye protection. Another author was responsible for removing the sawed splint and adding a new one between sawing, monitoring and controlling the measuring apparatus, and opening and closing the door between the splints in order to simulate the normal actions of a splint room. Before the start of the first set of sawing, the measuring devices were calibrated (the mass concentration of particles in the air before the start of sawing). Prior to analysis, the concentration of PM was obtained photometrically and was corrected by using the correction formula when compared with the gravimetric data as described by Bencetic Klaic et al. ${ }^{11}$.

The concentrations of calcium and sulfur in the samples of particulate matter were determined using the $\mathrm{X}$-ray fluorescence (XRF) method and analyzed by the ED XRF Epsilon 5 system (PANalytical, Almelo, The Netherlands). With the known chemical compo- sition of plaster $(\mathrm{CaSO} 42 \mathrm{H} 2 \mathrm{O})$ and relative atomic mass, the concentration of plaster in the collected airborne particle samples was calculated.

By collecting particulate matter in the air, it is possible to measure their aerodynamic diameter and concentration. When determining the ambient air quality, these particles are collected and the mass concentration of particulate matter with aerodynamic diameter less than 10 microns (PM10) and less than $2.5 \mathrm{mi}^{-}$ crons (PM2.5) is measured. For these measured fractions, there is a standardized maximum allowed concentration. The smallest fraction, PM1, was collected in order to study the potential health effects and to monitor the travelling range of this air pollution ${ }^{12}$.

Concerning working environment, there are clearly defined limit levels for plaster dust particles. The maximum Total Suspended Plaster Particle (TSPP) level is $10 \mathrm{mg} / \mathrm{m}^{3}$, the breathing fraction (PM2.5) level is $4 \mathrm{mg} / \mathrm{m}^{3}$, while short-term exposure levels (STEL) for plaster have not yet been defined according to the Croatian rules on limit values of exposure to hazardous substances at work and on biological limit values from $2009^{13}$ and amendments to the same regulations from $2013^{14}$.

\section{Results}

The first 12 plaster splints were sawn within a 60-minute interval. Sawing lasted between 3:00 and 6:00 minutes with the mean rate of 4.9 minutes per splint. After a break of 17 minutes, a second set of ten plaster splints were sawn within an interval of $18 \mathrm{~min}$ utes, with the mean cutting speed of 1.6 minutes. After one-hour break, the third series of 12 plaster splints were sawn with the mean cutting speed of 2.3 minutes. Figure 3 shows the mean serum fractions of dust particles in the casting room and waiting room, recorded every ten seconds.

The collected amount for the casting room (MP-1 and MP-2) and waiting room (MP-3 and MP-4), the calculation of the concentration of dust, plaster dust mass and percentage of plaster in the collected dust and PM10 fraction of particulate matter are shown in Table 1. The mean concentration of PM10 fraction of particulate matter in the casting room, measured by laser photometer over a period of $5 \mathrm{~h} 50 \mathrm{~min}$ amounted to $644.0 \mathrm{mg} / \mathrm{m}^{3}$. 
Table 1. Total mass and total concentration of dust, mass concentration and percentage of plaster dust for $P M_{10}$ fraction of airborne particles measured at 4 different locations

\begin{tabular}{|l|l|l|l|l|l|l|}
\hline MP & $\begin{array}{l}\mathrm{m} \\
(\mu \mathrm{g})\end{array}$ & $\begin{array}{l}\mathrm{V} \\
\left(\mathrm{m}^{3}\right)\end{array}$ & $\begin{array}{l}\mathrm{PM}_{10} \\
\left(\mu \mathrm{g} / \mathrm{m}^{3}\right)\end{array}$ & $\begin{array}{l}\mathrm{CaSO}_{4} \mathrm{x}_{2} \mathrm{H}_{2} \mathrm{O} \\
(\mu \mathrm{g})\end{array}$ & $\begin{array}{l}\mathrm{CaSO}_{4} \mathrm{x}_{2} \mathrm{H}_{2} \mathrm{O} \\
\left(\mu \mathrm{g} / \mathrm{m}^{3}\right)\end{array}$ & $\begin{array}{l}\mathrm{CaSO}_{4} \mathrm{xH}_{2} \mathrm{O} \\
(\%)\end{array}$ \\
\hline MP-1 & 2295.0 & 1.3 & 1738.6 & 2093.0 & 1585.6 & 91.2 \\
MP-2 & 1016.5 & 1.4 & 753.0 & 894.8 & 662.8 & 88.0 \\
MP-3 & 244.0 & 1.3 & 184.8 & 144.0 & 109.1 & 59.0 \\
MP-4 & 144.5 & 1.3 & 112.0 & 41.0 & 31.8 & 28.4 \\
\hline
\end{tabular}

$\mathrm{MP}=$ measuring point $\mathrm{m}=$ mass $; \mathrm{V}=$ volume; $\mathrm{PM}_{10}=$ particulate matter fraction with aerodynamic diameter of 10 microns

Table 2. Results for $P M_{2.5}$ fraction of airborne particles measured at 4 different locations

\begin{tabular}{|l|l|l|l|l|l|l|}
\hline MP & $\begin{array}{l}\mathrm{m} \\
(\mu \mathrm{g})\end{array}$ & $\begin{array}{l}\mathrm{V} \\
\left(\mathrm{m}^{3}\right)\end{array}$ & $\begin{array}{l}\mathrm{PM}_{2.5} \\
\left(\mu \mathrm{g} / \mathrm{m}^{3}\right)\end{array}$ & $\begin{array}{l}\mathrm{CaSO}_{4} \times 2 \mathrm{H}_{2} \mathrm{O} \\
(\mu \mathrm{g})\end{array}$ & $\begin{array}{l}\mathrm{CaSO}_{4} \times 2 \mathrm{H}_{2} \mathrm{O} \\
\left(\mu \mathrm{g} / \mathrm{m}^{3}\right)\end{array}$ & $\begin{array}{l}\mathrm{CaSO}_{4} \times 2 \mathrm{H}_{2} \mathrm{O} \\
(\%)\end{array}$ \\
\hline MP-1 & 593.0 & 1.3 & 449.2 & 440.9 & 334.0 & 74.4 \\
MP-2 & 302.0 & 1.4 & 223.7 & 207.9 & 154.0 & 68.8 \\
MP-3 & 120.5 & 1.3 & 91.3 & 36.6 & 27.7 & 30.4 \\
MP-4 & 90.5 & 1.3 & 68.6 & 15.2 & 11.5 & 16.8 \\
\hline
\end{tabular}

$\mathrm{MP}=$ measuring point; $\mathrm{m}=$ mass; $\mathrm{V}=$ volume; $\mathrm{PM}_{2.5}=$ particulate matter fraction with aerodynamic diameter of 2.5 microns

Table 3. Results for $P M_{10}-P M_{2.5}$ fraction of airborne particles measured at 4 different locations

\begin{tabular}{|l|l|l|l|l|l|l|}
\hline MP & $\begin{array}{l}\mathrm{m} \\
(\mu \mathrm{g})\end{array}$ & $\begin{array}{l}\mathrm{V} \\
\left(\mathrm{m}^{3}\right)\end{array}$ & $\begin{array}{l}\mathrm{PM}_{10}-\mathrm{PM}_{2.5} \\
\left(\mu \mathrm{g} / \mathrm{m}^{3}\right)\end{array}$ & $\begin{array}{l}\mathrm{CaSO}_{4} \times 2 \mathrm{H}_{2} \mathrm{O} \\
(\mu \mathrm{g})\end{array}$ & $\begin{array}{l}\mathrm{CaSO}_{4} \times 2 \mathrm{H}_{2} \mathrm{O} \\
\left(\mu \mathrm{g} / \mathrm{m}^{3}\right)\end{array}$ & $\begin{array}{l}\mathrm{CaSO}_{4} \times 2 \mathrm{H}_{2} \mathrm{O} \\
(\%)\end{array}$ \\
\hline MP-1 & 1702.0 & 1.3 & 1289.4 & 1652.1 & 1251.6 & 97.1 \\
MP-2 & 714.5 & 1.4 & 529.3 & 686.9 & 508.8 & 96.1 \\
MP-3 & 123.5 & 1.3 & 93.6 & 107.4 & 81.4 & 87.0 \\
MP-4 & 54.0 & 1.3 & 41.9 & 25.8 & 20.0 & 47.8 \\
\hline
\end{tabular}

$\mathrm{MP}=$ measuring point; $\mathrm{m}=$ mass; $\mathrm{V}=$ volume; $\mathrm{PM}_{10}-\mathrm{PM}_{2.5}=$ particulate matter fraction with aerodynamic diameter from 10 to 2.5 microns

Table 4. Mean mass concentration of airborne particles determined by laser photometer for each of the three sets of sawing

\begin{tabular}{|c|c|c|c|c|c|}
\hline & & $\begin{array}{l}\mathrm{PM}_{1} \\
\left(\mu \mathrm{g} / \mathrm{m}^{3}\right)\end{array}$ & $\begin{array}{l}\mathrm{PM}_{2.5} \\
\left(\mu \mathrm{g} / \mathrm{m}^{3}\right)\end{array}$ & $\begin{array}{l}\mathrm{PM}_{10} \\
\left(\mu \mathrm{g} / \mathrm{m}^{3}\right)\end{array}$ & $\begin{array}{l}\mathrm{PM}_{2.5} \\
\left(\mu \mathrm{g} / \mathrm{m}^{3}\right)\end{array}$ \\
\hline Sawing session & Time interval & \multicolumn{3}{|c|}{ Sawing room } & Waiting room \\
\hline 1 & $666-1000$ & 325.1 & 419.6 & 1056.2 & 29.4 \\
\hline 2 & $1100-1278$ & 476.7 & 611.0 & 1498.7 & 19.6 \\
\hline 3 & $1622-1944$ & 538.3 & 688.6 & 1662.3 & 42.1 \\
\hline
\end{tabular}

$\mathrm{PM}_{1}=$ particulate matter fraction with aerodynamic diameter of 1 micron; $\mathrm{PM}_{2.5}=$ particulate matter fraction with aerodynamic diameter of 2.5 microns; $\mathrm{PM}_{10}=$ particulate matter fraction with aerodynamic diameter of 10 microns 
The same parameters for the collected particulate matter with PM2.5 fraction are shown in Table 2. The mean concentration for PM2.5 fraction of airborne particles in the casting room after 5 hours and 50 minutes of measurement by laser photometer was $265.9 \mathrm{~g} / \mathrm{m}^{3}$.

The fraction of particulate matter with aerodynamic diameter between $2.5 \mu \mathrm{g}$ and $10 \mu \mathrm{g}$ (PM10-PM2.5) is also referred to as coarse particles (PMcoarse). Once inhaled, this fraction enters the thoracic part of the human respiratory system but does not reach the alveolar parts and is cleared by the ciliary mechanism. The results for this fraction of suspended particles are shown in Table 3. For PM10-PM2.5 particulate fraction, the mean particle concentration in the casting room measured by laser photometer over a period of 5 hours and 50 minutes was $378.1 \mathrm{~g} / \mathrm{m}^{3}$.

The mean mass concentration of particulate matter measured by laser photometer in the casting room and waiting room for each of the three sets of sawing is shown in Table 4.

\section{Discussion}

In everyday practice within the areas of plaster splint sawing (casting room), as well as in other neighboring rooms (waiting room), there is significant contamination of the air with plaster dust particles. This can be clearly seen in the air or on the objects where dust is being deposited. Protective equipment is not always required by legislation and there are no defined maximum concentrations and size (i.e. aerodynamic diameter) of the particle matter that poses a health risk to the employees and patients who are exposed to these areas.

In this study, we simulated the daily work activity and work spaces in which plaster immobilizations are sawed. We measured, recorded and calculated the fraction of plaster particles in the collected dust. We then compared the values depending on the distance from the sawing site and observed the changing dynamics of the concentrations depending on the frequency and duration of sawing plaster cast immobilizations.

In indexed medical journals, there are no studies that measure air pollution particles released in the areas where plaster immobilizations are sawed, especially inhalable particles of plaster that can cause acute respiratory problems and damage to lung function ${ }^{15,16}$.
Plaster dust irritates mucous membranes resulting in coughing and mucous secretion according to the material safety data sheet - Gypsum ${ }^{17}$. The term "pneumoconiosis", which literally means "dusty lung", is the result of dust accumulation in the lungs and tissue reactions that occur due to its presence. Plaster dust may not be corrosive, toxic or carcinogenic but it may be irritable to the lining of the lungs and respiratory tract ${ }^{18,19}$. Airways are lined with mucous membranes and cilia. Inhaled dust particles stick to the thick slimy layer of mucous membranes and the cilia are responsible for pushing them towards the throat, where they are expelled by coughing. If there are large concentrations of particles in the airways, the internal mechanisms of removal become overwhelmed and insufficient.

In Croatia, there are no regulations defining the required ventilation of the workspace where medical technicians work and saw plaster immobilizations. There is no legislation implementing safeguards or regulations for either plaster room or waiting room ${ }^{13,14}$.

There are five known effective methods for protection against dust, i.e. technological processes that generate less dust (vacuuming dust at the source); air purification; dilution of dust concentration using ventilation; isolation (separation of personnel from dusty atmosphere); and respirators/filters that remove dust from the air ${ }^{20}$. The need for these procedures could be defined after measuring pollution caused by normal dust particles of plaster.

As seen in Figure 3, the experiment (sawing) was performed in three different sets. The mean cutting speed per cast was changed from 4.9 minutes in the first sawing to 2.6 minutes for the second and $1.6 \mathrm{~min}$ utes for the last sawing. The measured values, shown in Figure 3, clearly indicate that the maximum concentration of dust in the air in both the casting room and waiting room was not proportional to the mean cutting speed. Furthermore, Table 4 shows that the mean concentration of all fractions in the casting room exceeded the previous one in each subsequent series of cutting. There are two reasons for this increase, i.e. the accumulation of particles from the previous sawing session in the air and re-suspension of the already precipitated particles originating from the preceding cutting, caused by movement of the workers and patients in the casting room, thus stirring up the already precipitated particles from various surfaces (floor, table, 
and other furniture) into the air, thus increasing their air concentrations.

Figure 3 shows a significant increase in dust concentrations during sawing and a decline during the break. The number of individual maximum concentrations (spikes) in the casting room corresponds to the total number of sawed plasters $(\mathrm{N}=34)$. In addition, the casting room concentrations for PM1 and PM2.5 were similar (i.e. smaller particles penetrate deep into the respiratory system; the smallest ones can enter the alveoli) and noticeably lower than the concentration of PM10 (which is kept in the upper respiratory tract). This means that the plaster sawing emits more noticeable large particles (coarse particles, PM10-PM2.5) than smaller particles of up to $2.5 \mu \mathrm{m}$ in size. This is not surprising since it is known that large particles are more frequently formed by mechanical action such as crushing or sawing ${ }^{21}$. The concentrations in the waiting room were significantly lower than in the sawing room, but there is clear jump in the concentration compared to the levels before plaster sawing. The pattern of maximum dust concentrations in the waiting room was also in correlation with plaster sawing.

After six hours of collecting PM10 fraction of particulate matter right next to the place of sawing, the highest concentrations of particles with aerodynamic diameter of less than 10 microns were recorded (Table 1). In the same area, only three feet away, the concentration was 2.3 times lower, while a decline was seen in the waiting room, where it was 10 times lower than at the source. Plaster dust made up the majority of the dust collected at the three measuring points, while at the farthest measurement point, in the waiting room, the plaster concentration in the dust measured less than $50 \%$. The rest of the particulate matter probably were organic remains of cotton and bandages. According to the results, it is obvious that these particles predominantly were found in smaller airborne fractions. Interestingly, in the sawing room at $3 \mathrm{~m}$ from the sawing point, the concentration of plaster in the dust fell by only about $3 \%$. In the waiting room, the dust concentration of plaster fell to about $30 \%$ when compared to the sawing room. As expected, the highest concentration of plaster dust was measured directly at the sawing site, while at $3-\mathrm{m}$ distance from that point, the concentration fell 2.3 times, and in the waiting room just outside the door of the sawing room the concentration fell 14.6 times.
During six hours of PM2.5 fraction particle collection, the highest concentration of particles of aerodynamic diameter less than 2.5 microns was found just next to the sawing site (Table 2). In the same room, at $3-\mathrm{m}$ distance from the sawing, the concentration fell to little more than half the original maximum value, while in the waiting room it fell more than ten times the maximum value. Plaster dust accounted for about $70 \%$ of the collected dust in the sawing room and less than one-third in the waiting room. Therefore, at the sawing site, the collected dust with aerodynamic diameter of less than 2.5 microns was made up of $91 \%$ plaster particles, and particle size 2.5-10 microns accounted for $97 \%$ of the total collected dust. In the waiting room, the PM2.5 fraction of particles collected accounted for only $30.4 \%$ of plaster dust, while the fraction of PM10-PM2.5 accounted for $87.0 \%$. In the socalled reference measurement site, in the waiting room at ten meters from the entrance to the sawing room, the particles with aerodynamic diameter of up to 2.5 microns were made up of only $16.8 \%$ plaster dust, and those with aerodynamic diameter of 2.5-10 $\mu \mathrm{m}$ were made up of $47.8 \%$ plaster particles.

After six hours of dust collection, the highest concentrations of particles with aerodynamic diameter greater than 2.5 and less than 10 microns (PM10PM2.5) were recorded at the measurement point directly next to the sawing site (Table 3 ). In the same room at 3-m distance from the sawing, the concentration fell just under 2.5 times the maximum, while in the waiting room, it fell more than ten times the maximum. Plaster dust accounted for $97 \%$ of the total collected dust in the sawing room and only about $10 \%$ in the waiting room.

The maximum concentrations and the maximum percentage of plaster particles for all measured fractions were recorded at the point of plaster sawing, and the lowest values were recorded at the greatest distances from that point. Plaster sawing forms particles of different sizes, but the largest percentage of these particles were found to be particles of larger size. The research results indicated that the inhalable plaster dust was mainly of larger size (PM10-PM2.5). During several hours of sawing, the mean concentration of dust fraction increased due to the accumulation and re-suspension of dust particles. However, the concentrations of plaster dust recorded were lower than the prescribed limit values for total and respiratory fraction in Croa- 
tia. It is reasonable to assume that during sawing of plaster splints, there are no harmful effects on the health of exposed health personnel and patients. However, the effects of prolonged exposures to plaster dust in health care personnel remain unknown.

\section{Acknowledgment}

This research was funded by the Institute of $\mathrm{Me}-$ dical Research and Occupational Health, Zagreb, Croatia.

\section{References}

1. Jones AP. Indoor air quality and health. Atmos Environ. 2009: 33:4535-64. doi: 10.1016/S1352-2310(99)00272-1

2. Dockery DW. Epidemiologic evidence of cardiovascular effects of particulate air pollution. Environ Health Perspect. 2001; 109(4):483-6. doi: 10.2307/3454657

3. Pope CA, Dockery DW. Health effects of fine particulate air pollution: lines that connect. J Air Waste Manag Assoc. 2006; 56(6):709-42. doi: 10.1080/10473289.2006.10464545

4. Sampson DH. Gypsum: Properties, Production and Applications. Hauppauge, Nova Science Publ Inc., New York; 2011.

5. McCauley JC. The use of plaster. Am J Surg. 1940;50(3):550-2.

6. Ramachandran G, Adgate JL, Hill N, Sexton K, Pratt GC, Bock D. Comparison of short-term variations (15-minute averages) in outdoor and indoor PM 2.5 concentrations. J Air Waste Manag Assoc. 2000;50(7):1157-66. doi: 10.1080/ 10473289.2000.10464160

7. Fromme H, Twardella D, Dietrich S, Heitmann D, Schierl R, Liebl B, et al. Particulate matter in the indoor air of classrooms - exploratory results from Munich and surrounding area. Atmos Environ. 2007;41(4):854-66. doi: 10.1016/j.atmosenv.2006.08.053

8. Shields KN, Cavallari JM, Hunt MJO, Lazo M, Molina M, Molina L, et al. Traffic-related air pollution exposures and changes in heart rate variability in Mexico City: a panel study. Environ Health. 2013;12:7. doi: 10.1186/1476-069X-12-7

9. Antabak A, Barišić B, Andabak M, Bradić L, Brajcinović M, Haramina T, et al. Physical properties of plaster bandages. Lijec Vjesn 2015;137(11-12):372-6.

10. Council Directive 1999/30/EC relating to limit values for sulphur dioxide, nitrogen dioxide and oxides of nitrogen, particu- late matter and lead in ambient air. Official Journal of the European Communities, 1999.

11. Bencetic Klaic Z, Ollier SJ, Babic K, Beslic I. Influences of outdoor meteorological conditions on indoor wintertime shortterm PM1 levels. Geofizika. 2015;32(2):237-64. doi: 0.15233/ gfz.2015.32.12

12. Sabbagh-Kupelwieser N. Urban aerosol studies of PM1 size fraction with reference to ambient conditions and visibility. Aerosol Air Qual Res.2010;10:425-32.doi: 10.4209/aaqr.2010. 02.0009

13. Pravilnik o graničnim vrijednostima izloženosti opasnim tvarima pri radu i o biološkim graničnim vrijednostima [Rulebook on borderline values of exposure to hazardous substances and on biological borderline values]. Official Gazette 2009;13. (in Croatian)

14. Pravilnik o izmjenama i dopunama Pravilnika o graničnim vrijednostima izloženosti opasnim tvarima pri radu i o biološkim graničnim vrijednostima [Rulebook on amendments to the Rulebook on borderline values of exposure to hazardous substances and on biological borderline values]. Official Gazette 2013;75. (in Croatian)

15. Oakes D, Douglas R, Knight K, Wusteman M, Mcdonald JC. Respiratory effects of prolonged exposure to gypsum dust. Ann Occup Hyg. 1982;26(8):833-40. doi: 10.1093/annhyg/26.8.833

16. Neghab M, Toosi M, Azad P. Respiratory morbidity associated with long-term occupational inhalation exposure to high concentrations of hydrated calcium sulfate dust. Occup Dis Environ Med. 2016;4:1-7. doi:10.4236/odem.2016.41001

17. Material safety data sheet - Gypsum (Calcium Sulfate Dihydrate) [Internet]. Available from: http://www.ncmissouri.edu/ hea/barton_epaosha/Gypsum Calcium Sulfate msds.pdf

18. McGee JK, Chen LC, Cohen MD, Chee GR, Prophete CM, Haykal-Coates N, et al. Chemical analysis of World Trade Center fine particulate matter for use in toxicologic assessment. Environ Health Perspect. 2002;111(7):972-80. doi:10.1289/ ehp.5930

19. Brun P, Kunz A, Funke M. Buried under gypsum powder - a rare respiratory complication. Respir Med Case Rep. 2013; 4(8):36-9. doi: 10.1016/j.rmcr.2013.01.002.eCollection 2013.

20. Beritić-Stahuljak D, Žuškin E, Valić F, Mustajbegović J. Medicina rada. $2^{\text {nd }}$ edn. Medicinska naklada, Zagreb; 1999. (in Croatian)

21. Wilson WE, Suh HH. Fine particles and coarse particles: concentration relationships relevant to epidemiologic studies. J Air Waste Manag Assoc. 1997;47(12):1238-49. doi: 10.1080/ 10473289.1997.10464074 


\section{Sažetak}

\section{ANALIZA PRAŠINE NASTALE PILJENJEM SADRENIH UDLAGA}

\section{A. Antabak, D. Halužan, A. Chouehne, M. Mance, N. Fuchs, I. Prlić, I. Bešlić i Z. Bencetić Klaić}

Sadrene udlage se svakodnevno rabe u kirurškoj i ortopedskoj praksi prilikom imobilizacije ozlijeđene djece i odraslih. Cilj ovoga rada bio je izmjeriti aerodinamički promjer i koncentraciju čestica prašine u zraku nastale piljenjem sadrenih udlaga (kalcijev sulfat dihidrat). Učinjeno je frakcionirano mjerenje lebdećih čestica prašine. Izmjerene frakcije, ovisno o respirabilnosti čestica, mogu imati određeno negativno djelovanje na ljudsko zdravlje. Mjerenja su provedena u laboratorijskim uvjetima, uz simulaciju bolničkih prostorija gipsaonice i njene čekaonice. Mjerenja u gipsaonici izvršena su pomoću dva para sakupljača čestica i jednog laserskog fotometra. Mjerenje u čekaonici provedeno je na jednak način. Prikupljena prašina po mjernim mjestima razlikuje se po aerodinamičkom promjeru i koncentraciji čestica gipsa u zraku. Najviše koncentracije čestica svih veličina zabilježene su neposredno uz mjesto piljenja. Na ostalim mjernim mjestima koncentracija čestica opada s udaljenošću od izvora prašine pri čemu je koncentracija prašine bila najniža u čekaonici. Zabilježene koncentracije prašine gipsa niže su od propisanih graničnih vrijednosti za ukupnu i respiracijsku frakciju u Hrvatskoj. Na temelju toga razumno je pretpostaviti da za vrijeme piljenja sadrenih udlaga nema štetnog učinka na zdravlje izloženih bolesnika i zdravstvenog osoblja.

Ključne riječi: Udlage, kirurške; Onečiščivači zraka - toksičnost; Ortopedska sredstva za fiksaciju; Prašina -štetna djelovanja 